\title{
The p16 ${ }^{\mathrm{INK4a}}$ Antibody Immobilization Method for Immonosensor Application
}

\author{
Li Yang ${ }^{13 *}$, Xian-He Huang ${ }^{1}$, Liang Sun ${ }^{2}$
}

\begin{abstract}
Background: The $16^{\mathrm{INK} 4 \mathrm{a}}$ is a protein that expressed in Liquid-based cervical cytology specimens and has been proved link to cervical cancer. The $\mathbf{p} 16^{\mathrm{INK} 4 \mathrm{a}}$ could be detection by piezoelectric immunosensor and the immobilization of the $16^{\mathrm{INK4a}}$ antibody influence the sensitivity of the piezoelectric immunosensor. Materials and Methods: $5 \mu \mathrm{L}$ mouse polyclonal antibody against $\mathrm{p}^{16^{\mathrm{INK} 4 \mathrm{a}}}$ was bound onto the surface of immonosensor through two methods. (directly immobilized method; protein A method). Absorb of the p16 ${ }^{\mathrm{INK} 4 \mathrm{a}}$ antibody on the surface of immonosensor caused a shift in the resonant frequency of the immunosensor and The frequency changes recorded showed a better reproducibility. The activity of the immobilization antibody with the directly method and protein A method was tested with p16 $^{\mathrm{INK4a}}$ antigen. Results: The resonant frequency for different antibody immobilization methods were different, and the sensitivity for p16 $^{\text {INK4a }}$ detection also different. Conclusions: The protein A method was found to be much more better than the directly method for the immobilization of the p16INK4A antibody on the gold electrode of the quartz crystal for cervical lesion detection. The Protein A method created more reproducible and stable immobilization antibody layers with p16INK4A antigen.
\end{abstract}

Keywords: $\mathrm{p} 16^{\mathrm{INK} 4 \mathrm{a}}$ - cervical cancer - protein A - antibody immobilization

Asian Pac J Cancer Prev, 16 (12), 5115-5118

\section{Introduction}

The cervical cancer is one of the most common cancers in developing Asian countries (Razak et al., 2013). The wide application of cytologic screening programs is a effective way in reducing cervical cancer incidence and mortality (Sahebali et al., 2006; Darragh et al., 2012; Eralp et al., 2013). Cervical screening using a Papanicolaou (Pap) test or liquid-based cytology to detect abnormal cells that may develop into cancer. If abnormal cells are found, women are invited to have a colposcopy. During a colposcopic inspection, biopsies can be taken and abnormal areas can be treated and prevent them from developing into cervical cancer. But, conventional cytologic diagnosis is often hampered by high false-negative rates compared with biopsy and interobserver variability (Bergeron et al., 2010). Another question arose as to whether all women with minimally abnormal tests needed such an expensive and uncomfortable procedure. We should find another ancillary test that could better separate those women who required colposcopy from those who did not. The use of biomarkers in both cervical cytology and histology has demonstrated the ability to overcome both false-positive and false-negative results, leading to improved positive predictive value of cervical screening results

Human papillomavirus (HPV) is the most common sexually transmitted infection (STI), nearly all sexually active men and women get it at some point in their lives.
Most HPV infections are subclinical and regress in two years; however, in Some people subclinical infections will become clinical and may cause benign papillomas (such as warts or squamous cell papilloma), or persistent infection with "high-risk" HPV types may progress to precancerous lesions and eventually into invasive cancer of the cervix, vulva, vagina, penis, oropharynx and anus (Ekalaksananan et al., 2006; Jing et al., 2013). Detection of molecular alterations caused by HPV in host cells could potentially be used as an adjunct to cytological screening. Among these candidate biomarkers, only $\mathrm{p} 16^{\mathrm{INK} 4 \mathrm{~A}}$, one of the cyclin-dependent kinase inhibitors, has sufficient evidence on which to make recommendations to apply to HPV-associated precancer lesions (Eleuterioet et al., 2009).

Previous studies suggested that amid most of the cancers, $\mathrm{p} 16^{\mathrm{INK} 4 \mathrm{~A}}$ protein is in under-expression while amid the cervical cancer, the $\mathrm{p} 16^{\mathrm{INK} 4 \mathrm{~A}}$ is over-expressed, and closely related to HPV infection and cervical cancer development (Ishikawa et al., 2006). Ishikawa also found that in the high-risk HPV the $\mathrm{p} 16^{\mathrm{INK} 4 \mathrm{a}}$ positive expression rates reached $32.4 \%, 82.1 \%, 93.2 \%$ and $100 \%$, it is obviously that all the HR-HPV specimens showed protein expression and the expression rate increased with the lesion progression. So, p16 ${ }^{\mathrm{INK} 4 \mathrm{a}}$ could be a biomarker to predict the outcomes of cervical lesions.

Immunosensor are device which utilize antigenantibody reactions for detecting target analytes. It could

${ }^{1}$ Frequency Control Laboratory, School of Automation \& Engineering, University of Electronic Science and Technology of China, ${ }^{2}$ Department of Pathology, West China Second University Hospital, Sichuan University, Chengdu, ${ }^{3}$ College of Electrical \& Information Engineering, Southwest University for Nationalities, Chengdu, Sichuan, China *For correspondence: yang9707@163.com 
LiYang et al

be used for clinical diagnose if the correct biomarker is choose. The quartz crystal microbalance (QCM) has been widely used as highly sensitive immunosensor because of the piezoelectricity property. The QCM commonly configure with electrodes on both sides of a thin disk AT-cut quartz which had nearly zero frequency drift with temperature around room temperature. In the late 1950s ,Sauerbrey found the relationship between resonant frequency and mass deposit onto surface of quartz in gas phase .Since the work of Sauerbrey, the quartz crystal microbalance (QCM) has been widely used to monitor slight mass change (nanogram) in many research area such as biology, physics, medicine and so on. The relationship of frequency to mass can be described as the Sauerbrey'sequation (Sauerbrey et al., 1956).

$$
\Delta f=-\frac{2 f_{0}^{2}}{A\left(\mu_{q} \rho_{q}\right)^{1 / 2}} \Delta m
$$

Where $\mathrm{f}_{0}$ is the operating frequency of the QCM, $\Delta f$ is the observed frequency change (in $\mathrm{Hz}$ ) caused by mass change. $\mu_{\mathrm{q}}$ and $\varrho_{\mathrm{q}}$ are the shear modulus and density of the crystal respectively, $\mathrm{A}$ is the active electrode area, and $\Delta \mathrm{m}$ is the mass change on the surface of the crystal (in ng). in this study, $\mathrm{f}_{0}$ equal to $10 \mathrm{MHz}, \mathrm{Q}_{\mathrm{q}}$ and $\mu_{\mathrm{q}}$ are equal to 2.65 $\mathrm{g} / \mathrm{cm}^{3}$ and $2.95 \mathrm{~N} / \mathrm{m}^{2}$ respectively. numerical substitution in Sauerbrey's equation yields:

$$
\Delta \mathrm{m}=2.213 \Delta \mathrm{f}
$$

Thus, if a substance with the weight of $1 \mathrm{ng}$ is homogeneously attached to the active area of crystal, a frequency change of $0.4518 \mathrm{~Hz}$.

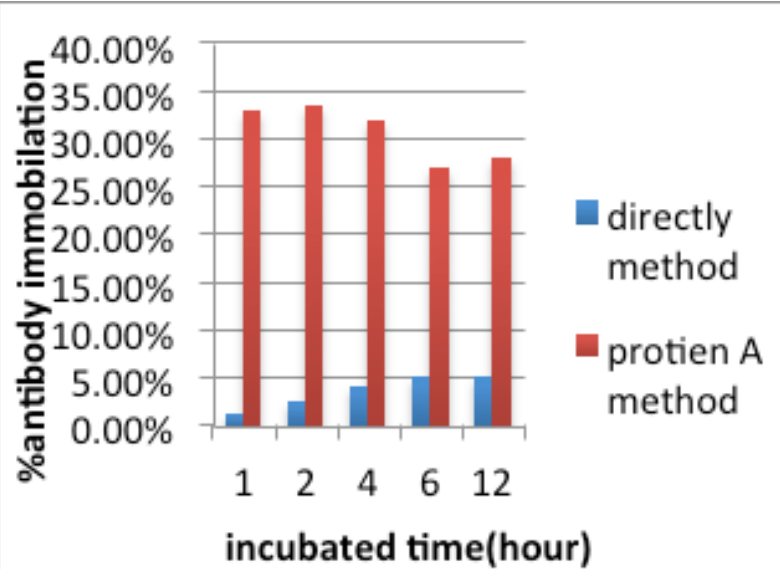

Figure 1. The Yield for Antibody Immobilization on Surfaces of Quartz Crystals at Different time with Directly Method and Protein A Method
Used the p16 $6^{\mathrm{INK} 4 \mathrm{a}}$ as a biomarker, the quartz crystal microbalance could be used as immonosensor for early cervical cancer detection. The immobilization of the p16 ${ }^{\mathrm{INK} 4 \mathrm{a}}$ antibody on the surface of QCM directly influence the sensitivity of the $\mathrm{p} 16^{\mathrm{INK} 4 \mathrm{a}}$ detection in supernatant of different clinical sample. It is very important to find a suitable immobilization method for $\mathrm{p} 16^{\mathrm{INK} 4 \mathrm{a}}$ antibody for early cervical cancer detection.

In this study, two methods for $\mathrm{p} 16^{\mathrm{INK} 4 \mathrm{a}}$ antibody immobilization were proposed. The effect of the immobilization methods on the resonant frequency of quartz crystal was observed and the activity of immobilized antibodies to $\mathrm{p} 16^{\mathrm{INK} 4 \mathrm{a}}$ antigen was tested.

\section{Materials and Methods}

\section{Materials}

Staphylococcal protein A(SPA) and blocking reagent bovine serum albumin (BSA) were purchased from Sigma Co. (U.S.A). Human P16 ${ }^{\mathrm{INK} 4 \mathrm{~A}}$ full length protein (ab84075) was purchased from Abcam Co. (U.S.A). Antibodies to p16 $6^{\mathrm{INK} 4 \mathrm{a}}$ (mouse monoclonal antibody, clone 6H12) were purchased from Maixin Co. (Huzhou, China). Phosphate-buffered saline (PBS) was composed of $137 \mathrm{mM} \mathrm{NaOH}, 2.7 \mathrm{mM}$ KCL, 8.0 mM Na2HPO4, and $1.5 \mathrm{mM} \mathrm{KH} 2 \mathrm{PO} 4$ (pH 7.2). All the PZ crystals were AT-cut and They were purchased from Tongfang Guoxin Electronics co., Ltd (Beijng, China). The crystal (diameter: $8 \mathrm{~mm}$ ) was placed between two gold electrodes, mounted in metal holder. An symmetric electrode pattern was used so that the upper electrode and the lower electrode had same radius $(2.5 \mathrm{~mm})$. The quartz crystal was driven at its resonant frequency with a homemade oscillator circuit and frequency measurement was performed with Agilent $531323 \mathrm{a}$, with a precision of $0.1 \mathrm{~Hz}$ at a gate time of $0.1 \mathrm{~s}$.

\section{Measurement procedures}

In order to detection the $\mathrm{p} 16^{\mathrm{INK} 4 \mathrm{a}}$ antigen, the antibody for $\mathrm{p} 16^{\mathrm{INK} 4 \mathrm{a}}$ was immobilized on the surface of piezoelectric quartz crystal.

\section{Directly immobilization}

In order to obtain a hydrophilic gold surface, the quartz crystal was dipped in $\mathrm{NaOH}$ and $\mathrm{HCl}$ for 10 minutes respectively, the concentration of the $\mathrm{NaOH}$ and $\mathrm{HCl}$ are all 1.2M. After this procedure, the quartz crystal was washed with dual-distilled water and ethanol twice, then drying at the room temperature. The fundamental

Table 1. The Frequency Shift Caused by Absorb of Antibody

\begin{tabular}{lcccccccccc}
\hline Crystal number & 1 & 2 & 3 & 4 & 5 & 6 & 7 & 8 & 9 & average \\
\hline$\Delta \mathrm{f}_{1}(\mathrm{~Hz})$ & 300 & 296 & 308 & 302 & 302 & 319 & 298 & 305 & 300 & 303 \\
$\Delta \mathrm{f}_{1}^{\prime}(\mathrm{Hz})$ & 1875 & 1762 & 1826 & 1895 & 1912 & 1937 & 1823 & 1917 & 1902 & 1876 \\
\hline
\end{tabular}

Table 2. The frequency shift caused by antibody-antigen reaction

\begin{tabular}{lcccccccccc}
\hline Crystal number & 1 & 2 & 3 & 4 & 5 & 6 & 7 & 8 & 9 & average \\
\hline$\Delta \mathrm{f}_{2}(\mathrm{~Hz})$ & 198 & 196 & 108 & 202 & 172 & 219 & 198 & 205 & 200 & 187.5 \\
$\Delta \mathrm{f}_{2}^{\prime}(\mathrm{Hz})$ & 920 & 904 & 895 & 901 & 903 & 890 & 900 & 907 & 902 & 902.45 \\
\hline
\end{tabular}


resonant frequency of the quartz crystal which record as F0 was measured by frequency counter. The $5 \mu \mathrm{l}(5 \mathrm{mg} /$ $\mathrm{ml}) \mathrm{P} 16^{\mathrm{INK} 4 \mathrm{~A}}$ antibody was directly dropped on the surface of cleaned quartz crystal by a $5-\mu \mathrm{L}$ syringe,. The quartz crystal which applied by $16^{\mathrm{INK} 4 \mathrm{~A}}$ antibody on the surface was incubated over silica gel blue at $4^{\circ} \mathrm{C}$. Different incubated time were performed (1hour, 2hourss, 6 hours, 12 hours) in order to get relationship between the yield for antibody immobilization to the incubated time. Finally, the crystal was dripped into PBS (PH7.2) solution and wash with distilled water twice, make the crystal air drying and the resonance frequency in gas phase (F1) was measured.

\section{Protein A immobilization}

The cleared procedure for quart crystal as described above. A $5 \mu \mathrm{L}$ staphylococcal protein A solution in PBS (pH 7.2) with concentration of the $1 \mathrm{mg} / \mathrm{mL}$ was evenly spread on the up side of the crystal for $20 \mathrm{~min}$, then rinse with distilled water to remove the excessive SPA solution, make the quartz crystal air drying and the frequency of QCM which record as $\mathrm{F}_{0}$ ' was measured. $5 \mu \mathrm{L}$ p16 ${ }^{\mathrm{INK} 4 \mathrm{a}}$ antibody solution with concentration of $5.0 \mathrm{mg} / \mathrm{mL}$ was applied to the crystal surface. the quartz crystal was incubated over silica gel blue at $4^{\circ} \mathrm{C}$ for different time (1 hour, 2hourss, 6 hours, 12hours), then dip the quartz crystal to PBS(PH7.2) solution and wash with distilled water twice, making air drying and measured the resonance frequency of quartz crystal and recorded as $\mathrm{F}_{1}$.

\section{Yield for antibody immobilization}

The mass on the crystal changed with the absorb of the antibody on the surface of quartz crystal. Because of the piezoelectric for quartz crystal, the resonant frequency of quartz crystals shifted. The Sauerbrey's equation give the relationship between shifted frequency to added mass. Then the yield for antibody immobilization was calculated as following equation:

$$
\% \text { antibody immobilization }=\Delta \mathrm{m} / \mathrm{m} \%
$$

Where $\Delta \mathrm{m}$ is the added mass caused by immobilized antibody, $\mathrm{m}$ is the mass for the antibody applied on the surface of quartz crystal. In this study, $5 \mu \mathrm{L}$ p $16^{\text {INK4a }}$ antibody solution with concentration of $5.0 \mathrm{mg} / \mathrm{mL}$ was applied on the crystals, so the m equal to $25 \mu \mathrm{g}$.

\section{Results}

\section{Determination of incubated time}

Nine quartz crystals were used in this study. All crystals were applied $\mathrm{p} 16^{\mathrm{INK} 4 \mathrm{a}}$ antibody through directly method and protein A method. After different incubated time, resonant frequency of crystals were measured. The frequency shift caused by absorb of antibody was calculated as eqution 4 and equation5:

$$
\begin{aligned}
& \Delta \mathrm{f}_{1}=\mathrm{F}_{0}-\mathrm{F}_{1}, \\
& \Delta \mathrm{f}_{1}^{\prime}=\mathrm{F}_{0}^{\prime}-\mathrm{F}_{1},
\end{aligned}
$$

Use the equation (2), the added mass caused by immobilized antibody $(\Delta \mathrm{m})$ was calculated, then the
$\%$ antibody immobilization was determination.

The relationship between \%antibody immobilization to incubated time for different method were showed as figur1 :

Figure1 The yield for antibody immobilization on surfaces of quartz crystals at different time with directly method and protein A method.

As shown in Figure1, the best incubated time for directly method to get higher yield of p16 $6^{\mathrm{INK} 4 \mathrm{a}}$ antibody immobilization is 6hours. The best incubated time for protein method is 1 hour.

\section{The form of the antibody layer}

For directly immobilization method, after 6hours incubated, the antibody layer was performed and the resonant frequency $\left(\mathrm{F}_{1}\right)$ was measured .The frequency shift caused by absorb of antibody was calculated as eqution 4 . For protein A immobilization method, after 1hours incubated, the resonant frequency $\left(\mathrm{F}_{1}^{\prime}\right)$ was measured. The frequency shift caused by absorb of antibody was calculated as eqution5, The resonant frequency shift for all nine quartz crystals were showed as table1:

Using the equation2 and equation3, the yield of antibody immobilization for directly method and protein A method were $5.32 \%$ and $33.16 \%$ respectively.

\section{The response for p16 ${ }^{I N K 4 a}$ antigen}

The antibody coated quartz crystals with directly method and protein A method were used to detect $\mathrm{p} 16^{\mathrm{INK} 4 \mathrm{a}}$ antigen. All the crystals were dipped into a stirred $2 \mathrm{~mL}$ PBS containing $1000 \mathrm{ng} / \mathrm{mL}$ of antigen (Human p16 $6^{\mathrm{INK} 4 \mathrm{~A}}$ full length protein) for $30 \mathrm{~min}$ at room temperature. When the reaction between the immobilized antibody and p16 $6^{\mathrm{INK} 4 \mathrm{~A}}$ was over, dip the quartz crystal to PBS (PH7.2) solution and wash with distilled water twice, making air drying and measured the resonance frequency of quartz crystal and recorded as $\mathrm{F}_{2}$. The frequency shifts specially induced by antibody-antigen reaction for directly method and protein A method were calculated as equation (6)a nd equation (7) respectively :

$$
\begin{aligned}
& \Delta \mathrm{f}_{2}=\mathrm{F}_{1}-\mathrm{F}_{2} \\
& \Delta \mathrm{f}_{2}^{\prime}=\mathrm{F}_{1}^{\prime}-\mathrm{F}_{2}
\end{aligned}
$$

The resonant frequency of all crystals changed. For directly method, the average frequency shift caused by $\mathrm{p} 16^{\mathrm{INK} 4 \mathrm{~A}}(2 \mathrm{ml} 1000 \mathrm{ng} / \mathrm{ml})$ was $187.5 \mathrm{~Hz}$. It is obviously that only $414 \mathrm{ng}$ p $16^{\mathrm{INK} 4 \mathrm{~A}}$ antigen was detection. For protein A method, the average frequency shift caused by $\mathrm{p} 16^{\mathrm{INK} 4 \mathrm{~A}}$ $(2 \mathrm{ml} 1000 \mathrm{ng} / \mathrm{ml})$ was $902.45 \mathrm{~Hz}$ and $1994 \mathrm{ng}$ p16 $6^{\mathrm{INK} 4 \mathrm{~A}}$ antigen was detection.

\section{Conclusion}

The protein A method was found to be much more better than the directly method for the immobilization of the $\mathrm{p} 16^{\mathrm{INK} 4 \mathrm{~A}}$ antibody on the gold electrode of the quartz crystal for cervical lesion detection. The Protein A method created more reproducible and stable immobilization antibody layers with $\mathrm{p} 16^{\mathrm{INK} 4 \mathrm{~A}}$ antigen. 


\section{References}

Bergeron C, Ordi J, Schmidt D, et al (2010). Conjunctive p $16^{\mathrm{INK} 4 \mathrm{~A}}$ testing significantly increases accuracy in diagnosing high-grade cervical intraepithelial neoplasia. Am $J$ Clin Pathol, 133, 395-406.

Darragh TM, Colgan TJ, Cox JT (2012). The lower anogenital squamous terminology standardization project for HPV-associated lesions: background and consensus recommendations from the college of American pathologists and the American society for colposcopy and cervical pathology. Arch Pathol Lab Med, 10, 1266-97

Ekalaksananan T, Pientong C, Sriamporn S, et al (2006) Usefulness of combining testing for $\mathrm{p} 16$ protein and human papillomavirus (HPV) in cervical carcinoma screening. Gynecol Oncol, 103, 62-6.

Eleuterioet J, Giraldo PC, Cavalcante DL (2009). Papillary squamous cell carcinoma of the uterine cervix, highrisk human papilloma virus infection and p16 (INK4a) expression: a case report. Acta Cytol, 53, 188-90.

Eralp B, Cihan T, Emre O, Sevgi A, et al (2013). Spermassociated antigen 9 is a promising marker for early diagnosis of endometrial cancer. Asian Pac J Cancer Prev, 14, 7635-9.

Ishikawa M, Fujii T, Saito M, et al (2006). Overexpression of $\mathrm{p} 16^{\mathrm{INK} 4 \mathrm{~A}}$ as an indicator for human papillomavirus oncogenic activity in cervical squamous neoplasia. Gynecol Cancer, 16, 347-53.

Jing L, Rong H, Johannes E, You L (2013). Epidemiological features of human papillomavirus (HPV) infection among women living in Mainland China. Asian Pac J Cancer Prev, 14, 4015-24

Razak NA, Mn K, Zubairi YZ, et al (2013). Estimating the fiveyear survival of cervical cancer patients treated in hospital universiti sains malaysia. Asian Pac J Cancer Prev, 14, 825-8.

Sahebali S, Depuydt CE, Boulet GAV (2006). Immunocytochemistry in liquid-based cervical cytology: analysis of clinical use following a cross-sectional study. Int J Cancer, 118, 1254-60.

Sauerbrey G (1958). Use of quartz vibrator for weighting thin film on a microbalance. $Z$ Phys, 155, 206-12. 